Original Research / Özgün Araştırma

\title{
Alternative Measurements to Waist Circumference in Diabetic Obese Females
}

\section{Diyabetik Obez Kadınlarda Bel Çevresine Alternatif Ölçüm Yöntemleri}

\author{
Sabah Tuzun ${ }^{* l}$, Can Öner ${ }^{l}$, Mehmet Akman ${ }^{2}$,Burak Ölmez ${ }^{3}$, Reşat Dabak ${ }^{l}$, Ekrem Orbay ${ }^{l}$
}

\begin{abstract}
Introduction: Although waist circumference measurement is frequently used for the assessment of abdominal fat mass, this method has some limitations. Among alternative anthropometric measurements, neck circumference is effective in reflecting the upper body fat distribution, whereas arm circumference is effective in reflecting insulin resistance. The present study aimed to evaluate the relationship between waist circumference and neck and arm circumferences in obese female patients with type 2 diabetes mellitus (DM).

Method: Diabetic female patients, who visited the Diabetes Outpatient Clinic between April and June 2015 and had a body mass index (BMI) of $\geq 30 \mathrm{~kg} / \mathrm{m}^{2}$, were enrolled in the study. Anthropometric measurements included body weight, height, BMI, waist circumference, neck circumference and both arm circumference in all participants.

Results: A total of 285 participants were included in the study; arm circumference was measured in $284(99.65 \%)$ and neck circumference was measured in $227(79.65 \%)$. Overall mean BMI was $37.4 \pm 5.6 \mathrm{~kg} / \mathrm{m}^{2}$, mean waist circumference was $117.8 \pm 12.1 \mathrm{~cm}$, mean neck circumference was $39.6 \pm 3.5 \mathrm{~cm}$, and mean arm circumference was $35.7 \pm 4.9 \mathrm{~cm}$. After adjusting for age and duration of DM, waist circumference showed strong positive correlation with BMI but moderately positive significant correlation with neck circumference and arm circumference $(p<0.001, p<0.001$ and $p<0.001$, respectively). Stepwise regression analysis, which was performed with the independent variables BMI, neck circumference and arm circumference for the dependent variable waist circumference, indicated that $B M I\left(R^{2}=0.544\right.$ and $\mathrm{p}<0.001)$, BMI and neck circumference $\left(\mathrm{R}^{2}=0.599\right.$ and $\left.\mathrm{p}<0.001\right)$ are significant. However, there was no significant relationship between waist circumference and arm circumference ( $\mathrm{p}>0.05)$

Conclusion: Waist circumference showed strong positive correlation with BMI but moderately positive correlation with neck and arm circumferences. Among anthropometric measurements, BMI has the highest efficacy in estimating waist circumference, whereas neck circumference has lower efficacy. Moreover, arm circumference has no significant effect in estimating waist circumference.
\end{abstract}

Key words: Type 2 Diabetes Mellitus, Anthropometry, Waist Circumference, Body Mass Index

\section{ÖZET}

Giriș: Abdominal yağ kitlesinin değerlendirilmesi amacıyla sıklıkla bel çevresi ölçümü kullanılmakla beraber, bel çevresi ölçümü ile ilgili kısıtllılıklar mevcuttur. Alternatif antropometrik ölçümlerden boyun çevresinin üst vücut yağ dağılımını gösterdiği ve kol çevresinin insulin direncini göstermede etkili olduğu saptanmıştır. Bu çalışma tip 2 diyabet hastası olan obez ve morbid obez kadınlarda bel çevresi ile boyun ve kol çevresi arasındaki ilişsinin değerlendirilmesini amaçlamaktadır.

Yöntem: Çalışmaya Diyabet Merkezi’ne Nisan - Haziran 2015 tarihleri arasında başvuran ve beden kitle indeksi (BKI) $\geq 30 \mathrm{~kg} / \mathrm{m}^{2}$ olan kadın DM hastaları dahil edilmiştir. Tüm katılımcıların antropometrik ölçüm değerlendirmelerinde vücut ağırlı̆̆ı, boy, BKİ, bel çevresi, boyun çevresi ve her iki kol çevresi ölçümleri değerlendirilmiștir.

Bulgular: Çalışmaya toplam 285 katılımcı kabul edilmiş olup 284 (\%99.65) katılımcının kol çevresi ve 227 (\%79.65) katılımcının boyun çevresi ölçümleri değerlendirilmiştir. Katılımcıların BKİ ortalaması $37.4 \pm 5.6 \mathrm{~kg} / \mathrm{m}^{2}$, bel çevresi ortalaması $117.8 \pm 12.1 \mathrm{~cm}$, boyun çevresi ortalaması $39.6 \pm 3.5 \mathrm{~cm}$ ve kol çevresi ortalaması $35.7 \pm 4.9 \mathrm{~cm}$ olarak tespit edilmiștir. Yas ve DM süresi control altına alındığında bel çevresi ile BKİ arasında güçlü pozitif, boyun ve kol çevresi arasında orta düzeyde pozitif anlamlı ilişki saptanmıştır (sırasıyla p $<0.001$, $\mathrm{p}<0.001$ ve $\mathrm{p}<0.001)$. Katılımcıların bel çevresi bağımlı değişkeni için BKİ, boyun ve kol çevresi bağımsız değişkenleri ile yapılan aşamalı regresyon analizinde $B K I \dot{I}\left(R^{2}=0.544\right.$ ve $\left.p<0.001\right)$, BKİ ve boyun çevresi $\left(R^{2}=0.599\right.$ ve $\left.p<0.001\right)$ anlamlı tespit edilmiştir. Bununla beraber, bel çevresi ve kol çevresi arasında ilişki saptanmamıştır ( $\mathrm{p}>0.05)$.

Tartışma: $\mathrm{Bu}$ çalışmada bel çevresi ile BKİ arasında güçlü pozitif ilişki saptanırken, boyun ve kol çevresi arasında orta düzeyde pozitif bir ilişki saptanmıştır. Bel çevresinin antropometrik ölçümlerle tahmin edilmesinde ise BKİ en yüksek etkinliğe sahipken, boyun çevresi daha düşük etkinlikte tespit edilmiștir. Ayrıca kol çevresinin ise bel çevresinin tahmin edilmesinde anlamlı etkisi saptanmamıştır.

Anahtar kelimeler: Tip 2 diabetes mellitus, Antropometri, Bel Çevresi, Beden Kitle İndeksi

Received Date / Geliş Tarihi: 08.06.2018 Accepted Date / Kabul Tarihi: 27.08.2018

${ }^{1}$ Kartal Dr Lütfi Kırdar Eğitim ve Araştırma Hastanesi, Aile Hekimliği Kliniği

${ }^{2}$ Marmara Üniversitesi Tıp Fakültesi Hastanesi, Aile Hekimliği Anabilim Dalı

${ }^{3}$ Sinanpaşa Küç̈̈khüyük Aile Sağlı̆̆ı Merkezi, Afyonkarahisar

*Address for Correspondence / Yazışma Adresi: Sabah Tuzun, Kartal Dr Lutfi Kırdar Eğitim ve Araştırma Hastanesi, Aile Hekimliği KliniğiE-Mail:sabahtuzun@gmail.com

Tuzun S, Öner C, Akman M, Ölmez B, Dabak R, Orbay E. Diyabetik Obez Kadınlarda Bel Çevresine Alternatif Ölçüm Yöntemleri. TJFMPC, 2019;13 (1):22-27. DOI: 10.21763/tjfmpc.527970. 


\section{INTRODUCTION}

Although body mass index (BMI) is widely used for the definition and classification of obesity, which has increasing prevalence worldwide, there are limitations in evaluating body fat percentage and fat distribution by means of BMI ${ }^{1-3}$ In addition, abdominal fat mass, which is one of the most important risk factors for type 2 diabetes mellitus (DM), hypertension and cardiovascular diseases, is most frequently evaluated by means of waist circumference measurement. ${ }^{2-4}$ Nevertheless, waist circumference measurement has some limitations such as the absence of definite anatomical points, difficulty in applying the anatomical points in use to obese subjects, frequent measurement errors, showing differences during the day in the same subject, and being not practical for the screening of large populations because of thick clothing particularly in winter season. ${ }^{3}$ For these reasons, recent investigations have focused on a new method that would substitute waist circumference measurement. ${ }^{3,5}$ There are studies indicating that neck circumference measurement, which is a more applicable method than the waist circumference measurement, might be an alternative method for assessing upper body fat distribution. ${ }^{5-7}$ Besides, although arm circumference, another easily applicable anthropometric measurement, has been determined to be effective in reflecting insulin resistance, the literature reveals that it is usually used to evaluate malnutrition in the pediatric and geriatric populations. ${ }^{5,8,9}$ The present study aimed to evaluate the relationship between waist circumference measurement and neck and arm measurements, which are among the other anthropometric measurements, in obese and morbid obese diabetic females.

\section{METHOD}

Study Universe: The present study comprises the female DM patients, who visited Kartal Dr. Lütfi Kurdar Training and Research Hospital, Pendik Kaynarca Diabetes Center between April and June 2015 and had BMI of $\geq 30 \mathrm{~kg} / \mathrm{m}^{2}$. Regarding the classification of obesity according to the BMI of the participants, those with BMI of $30.00-34.99 \mathrm{~kg} / \mathrm{m}^{2}$ were defined as class I obesity, with BMI of 35.00$39.99 \mathrm{~kg} / \mathrm{m}^{2}$ were defined as class II obesity, and with BMI of $\geq 40 \mathrm{~kg} / \mathrm{m}^{2}$ were defined as class III obesity. ${ }^{10}$ The study was approved by the local ethics committee of Kartal Dr. Lütfi Kurdar Training and Research Hospital (Protocol No: 89513307/1009/487, Decision No:68).

Measurements used in the Study: Anthropometric measurements included body weight, height, BMI, waist circumference, neck circumference, and both arm circumferences in all study participants. For height and body weight measurement, DESIS height and weight scale with $0.1 \mathrm{~kg}$ sensitivity, which is being calibrated periodically, was used. Waist, neck and bilateral arm circumferences were measured using a standard measuring tape. Among the anthropometric measurements, waist circumference was measured as the distance around the belly passing through the umbilical point on the anterior abdominal wall and including both superior iliac spines. Neck circumference was measured as the distance around the neck passing through the middle part of the cervical spine and the laryngeal process. Arm circumferences of the participants were measured as the distance around the upper arm passing through the midpoint between the acromion process of the shoulder and olecranon process of the elbow joint, and then the arithmetic mean of two arm circumferences was calculated. All measurements were performed by the same researcher over the skins of the participants with the shoes off.

Exclusion criteria: Patients with type 1 diabetes mellitus or with prediabetes, pregnant women, patients with chronic liver disease, chronic kidney disease and Cushing syndrome were not included in the study. In addition, neck circumference in the patients with thyroid disease or the history of thyroidectomy as well as the arm circumference of the patients with the history of mastectomy was not included in the analyses.

Statistical analysis: SPSS 22.0 program was used for the statistical analysis of the study data. Statistical evaluation included descriptive analyses (frequency, mean \pm standard deviation, median, and minimum-maximum) and the One-way ANOVA test for the comparison of continuous variables with normal distribution between the groups. Pearson's correlation analysis was performed to assess the relationship between the continuous variables showing normal distribution. Moreover, waist circumference was used as the dependent variable in linear regression and stepwise regression analyses, whereas BMI, neck circumference and arm circumference were used as the independent variables. In all of the statistical analyses, $p<0.05$ was considered statistically significant.

\section{RESULTS}

A total of 285 patients were enrolled in the study; arm circumference was measured in 284 (99.7\%) and neck circumference was measured in 227 (79.7\%) of these participants. Arm circumference was not measured in one of the participants $(0.35 \%)$ because of the history of mastectomy, and neck circumference was not measured in $58(20.4 \%)$ of the participants because of the presence of thyroid disease. Of the participants, the mean age was $56.2 \pm 9.8$ years, the mean $\mathrm{HbAlc}$ value was $7.8 \pm 1.5 \%$ and the median duration of DM was 12.0 (0.0-36.0) years. With regard to the anthropometric 
parameters, the mean BMI value was $37.4 \pm 5.6$ $\mathrm{kg} / \mathrm{m}^{2}$, the mean waist circumference was $117.8 \pm 12.1 \mathrm{~cm}$, the mean neck circumference was $39.6 \pm 3.5 \mathrm{~cm}$, and the mean arm circumference was $35.7 \pm 4.9 \mathrm{~cm}$.

Evaluating the relationship between waist circumference and the other anthropometric measurements, a significant relationship was determined between waist circumference and BMI, neck circumference and arm circumference ( $\mathrm{r}=0744$ and $\mathrm{p}<0.001 ; \mathrm{r}=0.529$ and $\mathrm{p}<0.001 ; \mathrm{r}=0.548$ and $\mathrm{p}<0.001$, respectively). It was observed that the relationship between anthropometric measurements persisted after adjusted for age and duration of DM. The relationship between anthropometric measurements after adjusting for age and duration of DM is summarized in Table 1.
Stepwise regression analysis, which was performed for the estimation of waist circumference using BMI, neck circumference and arm circumference, revealed a relationship with BMI and neck circumference, whereas no significant relationship was determined with arm circumference $(\mathrm{p}<0.001$, $\mathrm{p}<0.001$ and $\mathrm{p}=192$, respectively). Estimation of waist circumference using the other anthropometric measurements is summarized in Table 2.

When the participants with available neck circumference measurement were evaluated according to the BMI groups, it was determined that $97(42.7 \%)$ were in class I obesity group, 72 $(31.7 \%)$ were in class II obesity group, and 58 $(25.6 \%)$ were in class III obesity group. Evaluating the participants with available arm circumference measurement according to the BMI groups, it was observed that $117(41.2 \%)$ were in class I obesity group, $96(33.8 \%)$ were in class II obesity group, and $71(25.0 \%)$ were in class I obesity group.

\section{Table 1. Relationship between anthropometric measurements after adjusting for age and duration}

of DM

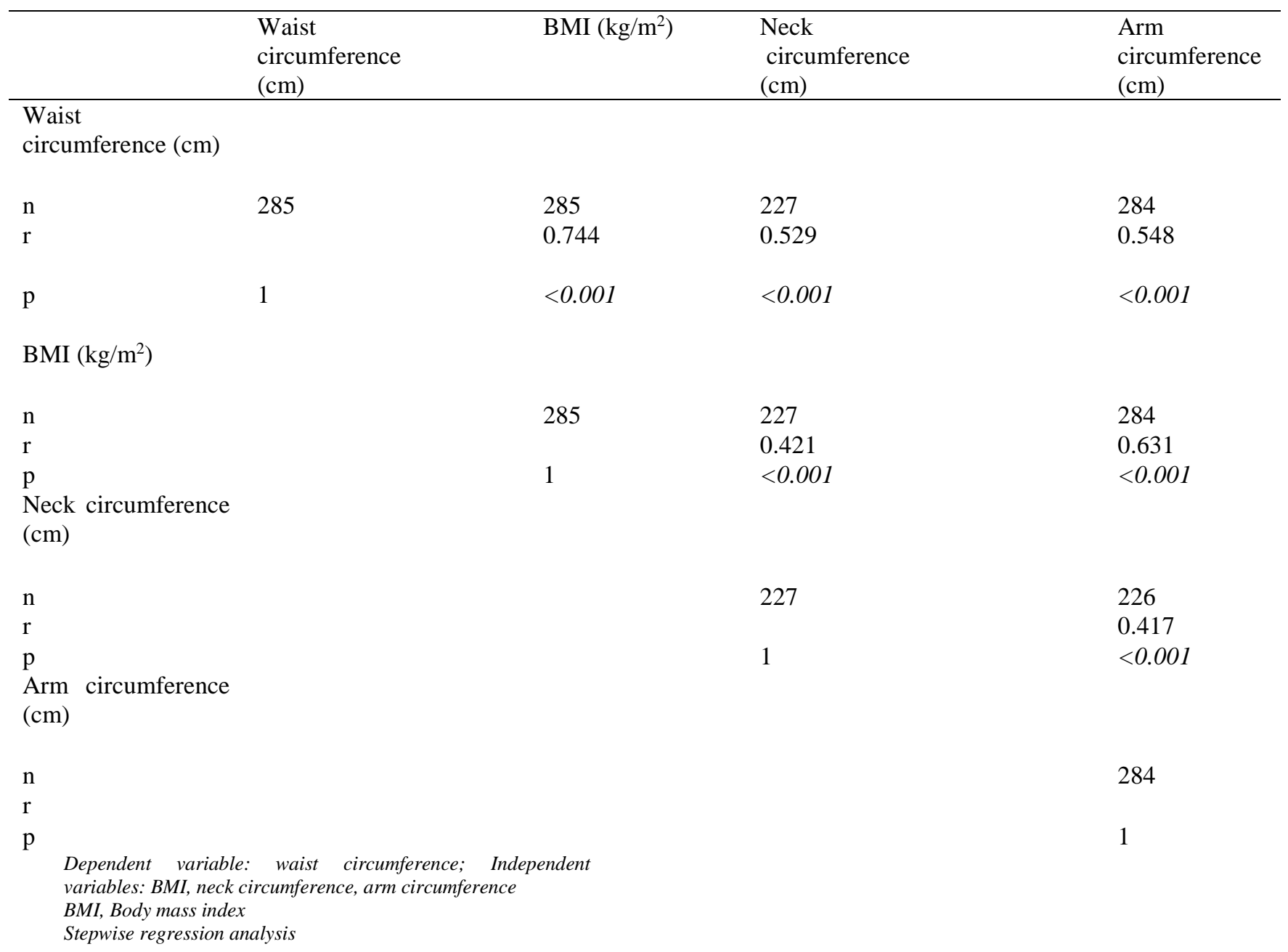


Table 2. Estimation of waist circumference using other anthropometric measurements

\begin{tabular}{lllll}
\hline Model & \multirow{2}{*}{ Adjusted $\mathrm{R}^{2}$} & Variables & \multicolumn{2}{l}{ Coefficients } \\
\cline { 3 - 4 } & & & Beta & $\mathrm{p}$ \\
\hline 1 & BMI & 0.739 & $<0.001$ \\
1 & & & $<0.001$ \\
2 & & BMI & 0.633 & $<0.001$ \\
\hline
\end{tabular}

BMI, Body mass index, Pearson correlation test

\begin{tabular}{llllllll}
\hline \multicolumn{6}{l}{ Table 3. Anthropometric measurements according to the obesity groups } & \\
\hline & \multicolumn{2}{l}{ Class I obesity } & \multicolumn{2}{c}{ Class II obesity } & Class III obesity & & $\mathrm{p}$ \\
\cline { 2 - 7 } & $\mathrm{n}(\%)$ & Mean & $\mathrm{n}(\%)$ & Mean & $\mathrm{n}(\%)$ & Mean & \\
\hline BMI $\left(\mathrm{kg} / \mathrm{m}^{2}\right)$ & $118(41.40)$ & $32.8 \pm 1.4$ & $96(33.68)$ & $37.2 \pm 1.5$ & $71(24.92)$ & $45.3 \pm 4.6$ & $<0.001$ \\
Waist circumference $(\mathrm{cm})$ & $118(41.40)$ & $108.9 \pm 7.7$ & $96(33.68)$ & $119.1 \pm 7.9$ & $71(24.92)$ & $130.6 \pm 10.8$ & $<0.001$ \\
Neck circumference $(\mathrm{cm})$ & $97(42.73)$ & $38.2 \pm 3.2$ & $72(31.72)$ & $40.1 \pm 3.0$ & $58(25.55)$ & $41.4 \pm 3.6$ & $<0.001$ \\
Arm circumference $(\mathrm{cm})$ & $117(41.20)$ & $32.9 \pm 3.4$ & $96(33.80)$ & $35.3 \pm 3.4$ & $71(25.00)$ & $40.6 \pm 5.1$ & $<0.001$ \\
\hline
\end{tabular}

BMI, Body mass index, One way ANOVA test

Anthropometric measurements according to the obesity groups are summarized in Table 3 .

While the waist circumference measurement in Class I obesity group showed a relationship with BMI and neck circumference, no significant relationship was determined with arm circumference $(\mathrm{r}=0.229$ and $\mathrm{p}=0.013 ; \mathrm{r}=0.303$ and $\mathrm{p}=0.003 ; \mathrm{r}=0.030$ and $\mathrm{p}=0.749$, respectively). In Class II and Class III obesity groups, waist circumference measurements showed significant correlation with BMI, neck circumference and arm circumference $(r=0.368$ and $\mathrm{p}<0.001 ; \mathrm{r}=0.398$ and $\mathrm{p}<0.001 ; \mathrm{r}=0.247$ and $\mathrm{p}=0.015$, respectively for class II obesity group. $\mathrm{r}=0.493$ and $\mathrm{p}<0.001$; $\mathrm{r}=0.489$ and $\mathrm{p}<0.001 ; \mathrm{r}=0.491$ and $\mathrm{p}=0.015$, respectively for class III obesity group).

\section{DISCUSSION}

The present study determined a significant positive correlation between waist circumference and BMI, whereas moderate positive correlation was determined with neck circumference and arm circumference. With regard to the estimation of the waist circumference using anthropometric measurements, BMI had the highest accuracy while neck circumference had lower efficacy. In addition, arm circumference had no significant efficacy in estimating waist circumference. According to the obesity groups, waist circumference showed significant positive correlation with BMI and neck circumference in all groups of obesity. Nevertheless, while there was no correlation between waist circumference and arm circumference in the Class I obesity group, low and moderate correlation was determined in Class II and Class III obesity groups, respectively.

There is a large margin of error in measuring the waist circumference, which is used for the assessment of abdominal obesity. ${ }^{11}$ In a study, error probability was determined to be the highest for waist and hip circumference measurements and to be the lowest for height and weight measurements among anthropometric measurements performed by the physicians, and it was observed that BMI is more accurate measurement than the waist and hip circumferences. ${ }^{11} \mathrm{~A}$ study determined that waist circumference has the highest correlation with BMI among the anthropometric measurements. ${ }^{5}$ In the present study, likewise, the highest correlation was determined between waist circumference and BMI. Nevertheless, many studies use waist circumference, waist/hip ratio and waist/height ratio as BMI does not reflect the amount and distribution of body fat. ${ }^{2,4,12}$ Because of all these limitations, new methods of anthropometric measurement have been tried to be developed in the recent days. ${ }^{6,7,12}$ There are studies indicating that neck circumference is more accurate than BMI and applied more easily than waist circumference in evaluating central obesity in overweight and obese subjects. $^{3,5}$ In a population-based study, neck circumference was found to be a good indicator of body fat distribution and visceral adipose tissue and that it could be a marker for metabolic syndrome. ${ }^{3}$ Earlier studies determined a significant correlation between neck circumference and BMI and waist circumference. ${ }^{1,3,4,6,7,13}$ A study determined a correlation between neck circumference and waist circumference in the subjects both with and without DM. $^{7}$ Moreover, it was found that neck circumference could be a marker for the 
development of insulin resistance and DM and that increased neck circumference is associated with increased risk of development of DM. . $^{1,6,7,14,15}$ Likewise, the present study found a relationship between neck circumference and waist circumference and determined that the likelihood of BMI and neck circumference are estimating the waist circumference is nearly $60 \%$. BMI is the most effective anthropometric measurement by $54 \%$ in estimating the waist circumference, where neck circumference has low efficacy.

In the literature, arm circumference is frequently used to assess the nutritional status and malnutrition in children and geriatric subjects. ${ }^{8}$ A study determined a positive correlation between arm circumference and BMI and waist circumference. ${ }^{5}$ Another study determined that waist circumference and arm circumference are effective in demonstrating insulin resistance in non-obese old people. ${ }^{9}$ In a study evaluating the wrist circumference as an anthropometric parameter of the upper extremity, wrist circumference was found to be correlated with BMI and waist circumference and it was determined that wrist circumference can be a marker for the development of DM and metabolic syndrome. ${ }^{16}$ In the present study, although a moderate correlation was found between the waist circumference and arm circumference, arm circumference was determined as not effective in estimating the waist circumference.

The limitation of the present study is the inclusion of patients newly diagnosed with DM, of whom the anthropometric measurements have not been influenced by DM yet. As a result of aging and duration of diabetes, there is an increase in total body fat mass and BMI $(2,17)$. Therefore, there may be differences in anthropometric measurements among patients newly diagnosed and long-term with DM.

In conclusion, new methods of anthropometric measurement are tried to be developed in the recent years because of a large margin of error in waist circumference measurement and the BMI's not reflecting the body fat distribution. There are studies indicating that neck circumference among these measurements could be useful in detecting abdominal obesity in obese subjects and that arm circumference might be an indicator of insulin resistance in non-obese subjects. In the present study, a strong positive correlation was determined between waist circumference and BMI in obese DM females, whereas moderate positive correlation was determined with neck and arm circumferences. While BMI among anthropometric measurements has the highest efficacy in estimating waist circumference, neck circumference was found to be of lower efficacy. Moreover, arm circumference was found not significantly effective in estimating waist circumference.
Conflict interest: None.

Funding Source: There was no funding source for this study.

\section{REFERENCES}

1. Wang X, Zhang N, Yu C, Ji Z. Evaluation of neck circumference as a predictor of central obesity and insulin resistance in Chinese adults. Int J ClinExp Med 2015;8(10):1910713.

2. Gelber RP, Gaziano JM, Orav EJ, Manson JE, Buring JE, Kurth T. Measures of obesity and cardiovascular risk among men and women. J Am Coll Cardiol2008;52:605-15.

3. Stabe C, Vasques ACJ, Lima MMO, Tambascia MA, Pareja JC, Yamanaka A, et al. Neck circumference as a simple tool for identifying the metabolic syndrome and insulin resistance: Results from the Brazilian Metabolic Syndrome Study. Clin Endocrinol (Oxf) 2013;78(6):874-81.

4. Qureshi NK, Hossain T, Hassan MI, Akter N, Rahman MM, Sultana MM, et al. Neck Circumference as a Marker of Overweight and Obesity and Cutoff Values for Bangladeshi Adults. Indian J Endocrinol Metab 2017;21(6):803-808.

5. Mason C, Craig CL, Katzmarzyk PT. Influence of central and extremity circumferences on allcause mortality in men and women. Obesity (Silver Spring) 2008;16(12):2690-5.

6. Cho NH, Oh TJ, Kim KM, Choi SH, Lee JH, Park KS, et al. Neck circumference and incidence of diabetes mellitus over 10 Years in the Korean Genome and Epidemiology Study (KoGES). Sci Rep 2015;5:18565.

7. Aswathappa J, Garg S, Kutty K, Shankar V. Neck circumference as an anthropometric measure of obesity in diabetics. N Am J Med Sci 2013;5(1):28-31.

8. Tang AM, Dong K, Deitchler M, Chung M, Maalouf-Manasseh Z, Tumilowicz A, et al. Use of cutoffs for mid-upper arm circumference (MUAC) as an indicator or predictor of nutritional and health-related outcomes in adolescents and adults: A systematic review. 2013. Food and Nutrition Technical Assistence III Project (FANTA). https://www.fantaproject.org/sites/default/files/ resources/MUAC\%20Systematic\%20Review\% 20_Nov\%2019.pdf (accessed 30 March 2018).

9. Chao YP, Lai YF, Kao TW, Peng TC, Lin YY, Shih MT, et al. Mid-arm muscle circumference as a surrogate in predicting insulin resistance in non-obese elderly individuals. Oncotarget 2017;8(45):79775-79784.

10. World Health Organization. BMI classification. 
http://apps. who.int/bmi/index.jsp?introPage=in tro_3.html (accessed 12 January 2018).

11. Sebo $P$, Haller D, Pechère-Bertschi A, Bovier P, Herrmann F. Accuracy of doctors' anthropometric measurements in general practice. Swiss Med Wkly 2015;145:w14115.

12. Chang Y, Guo X, Chen Y, Guo L, Li Z, Yu S, et al. A body shape index and body roundness index: two new body indices to identify diabetes mellitus among rural populations in northeast China. BMC Public Health 2015;15:794.

13. Yang GR, Yuan SY, Fu HJ, Wan G, Zhu LX, $\mathrm{Bu} \mathrm{XL}$, et al; Beijing Community Diabetes Study Group. Neck circumference positively related with central obesity, overweight, and metabolic syndrome in Chinese subjects with type 2 diabetes: Beijing Community Diabetes Study 4. Diabetes Care 2010;33(11):2465-7.

14. Khalangot M, Gurianov V, Okhrimenko N, Luzanchuk I, Kravchenko V. Neck circumference as a risk factor of screendetected diabetes mellitus: community-based study. DiabetolMetabSyndr2016;8:12.

15. Freedman DS, Rimm AA. The relation of body fat distribution, as assessed by six girth measurements, to diabetes mellitus in women. Am J Public Health 1989;79(6):715-20.

16. Noudeh YJ, Hadaegh F, Vatankhah N, Momenan AA, Saadat N, Khalili D, et al. Wrist circumference as a novel predictor of diabetes and prediabetes: Results of cross-sectional and 8,8-year follow-up studies. J Clin Endocrinol Metab 2013; 98(2): 777-84.

17. Tanvir A, Nadim H. Assessment and management of nutrition in older people and its importance to health. Clin Interv Aging 2010;5:207-16. 